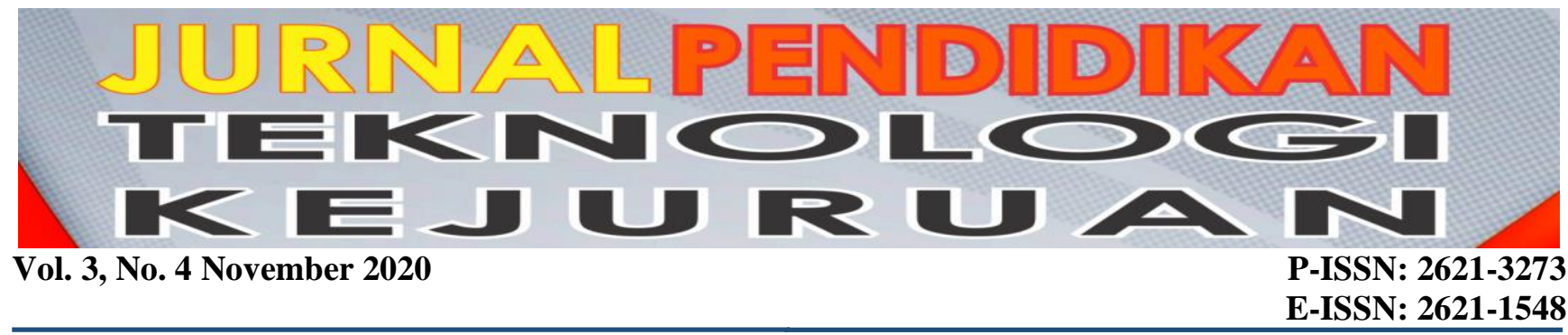

\title{
Technopreneurship and IT-Preneurship in Vocational Education Perspective: Perspective Theory
}

\author{
Rizki Hardian Sakti ${ }^{1}$, Wirda Yetti ${ }^{2}$, Risky Ema Wulansari ${ }^{3}$ \\ ${ }^{123}$ Universitas Negeri Padang \\ *Corresponding author, e-mail: rizki.hardian29@gmail.com
}

\begin{abstract}
This study aimed to examine a descriptive review of technopreneurship and IT-preneurship viewed from an aspect of vocational education perspective. Descriptively, this research will provide an overview of the technopreneurship and IT-preneurship that must be possessed by vocational tertiary institutions. Technopreneurship and IT-preneurship is one part of entrepreneurship based on technology. The world of vocational education is obliged to produce generations who not only have an entrepreneurial spirit, but also have a spirit of technopreneurship and IT-preneurship. Communicating important technology in developing entrepreneurial spirit is a challenge for the world of vocational education. This article is a conceptual paper related to publish publications related to the themes in this article and this article discusses the concepts of technopreneurship and IT preneurship in the perspective of vocational education and also enhances entrepreneurship development in the world of vocational education.
\end{abstract}

Keywords: Technopreneurship, IT-preneurship, Vocational Education

\section{INTRODUCTION}

In the current globalization era, humans are required to be able to compete with each other in various sectors of life. Especially in the Industrial Revolution 4.0 era, where information technology has become the basis of human daily life. The industrial revolution 4.0 moves towards the socio-technologydigital era, everything becomes limitless by using unlimited computing and data, because it is influenced by the development of the internet and digital technology as the backbone of movement and connectivity between humans, machines and digital technology (Vojtovič et al., 2016). This era also affects several human activities, including in the entrepreneurship, knowledge and technology sectors (Lee et al., 2014).

It requires Indonesia to prepare human resources with the necessary skills. It is estimated that in 2035 the population of Indonesia will reach 306.5 million. During the same period, the working age or productive age increased to 204.7 million people. Productive age reaches around 60 percent and the dependency ratio reaches $40 \%$. This means that in 2035 around 6 people will support 4 unproductive people (Statistik, 2019).

Based on the Tingkat Pengangguran Terbuka (TPT) data released by the Badan Pusat Statistik in August 2019, it explains that TPT for the vocational education level (SMK) is the highest, reaching $10.42 \%$ (Statistik, 2019).

In order to respond it, Indonesian vocational education, even vocational high schools, universities and other vocational institutions have to focus on preparing quality human resources to be able to compete in this era of the Industrial Revolution 4.0. Indonesia can prepare quality human resources through vocational education because of the philosophy of vocational education, which is carried out to meet the community and industrial needs that will be in locations where vocational education will be held (Usman \& Raharjo, 2012).

The orientation of vocational education must be aimed at success in the output or graduation that can answer the needs of the labor market. Furthermore, the success of the education program is completely oriented towards the quality of its graduates in the business and industrial world (Ganefri, 2013).

Entrepreneurship is one of the creative and innovative skills that a person must have to face of the Industrial Revolution 4.0 era, even an engineer (Güney-frahm, 2018). The spirit of entrepreneurship that is belonged by a person is not only about trading, it is not only about academic intelligence and skills in producing a product. However, the spirit of entrepreneurship has a broad meaning, the spirit of entrepreneurship can be said to be the dynamic soul 
possessed by a person in capturing risks and challenges, and turning them into opportunities and potentials to continue to advance and develop (W. Hartono, 2011).

Along with the times that have got into the era of the Industrial Revolution 4.0. entrepreneurship has also developed towards a technology base, known as technopreneurship and IT-preneurship.

Technopreneurship and IT-preneuership have been skills and these are strategic forces in this era of the Industrial Revolution 4.0, with all activities surrounded by technology. Technopreneurship and IT-preneurship are part of entrepreneurship, where technopreneurship and IT-preneurship use basic technological innovations in entrepreneurship. The entrepreneurial tools used in technopreneurship and IT-preneurship are based on a technology base (Harsono, 2013). In essence, technopreneurship and IT-preneurship combine entrepreneurship and technology (Kosasih et al., 1991).

This is a new challenge for vocational education. The industrial revolution 4.0 not only opens the flow of trade in goods and services, but also professional human resources, this is a challenge for vocational education to produce students who are ready to compete (Rojko, 2017). Vocational education must be able to create graduates who not only have an entrepreneurial spirit but also have a technopreneur and IT-preneur spirit.

Basically, vocational education is one of the important keys in the sector of building the nation and state. Vocational education plays an important role in preparing their graduates to compete in this digitalization era. Today, vocational education is looking for the best way to learn skills in the era of the Industrial Revolution 4.0. One of the skills that support in order to compete in the era of the Industrial Revolution 4.0 is the spirit of technoprenership and IT-preneurship (Purnomo et al., 2018)(Wahyudi \& Tileng, 2017).

Through promoting vocational education in the technopreneurship and IT preneurship fields, it is expected that vocational education graduates will have a dynamic spirit in facing obstacles and risks and turning them into opportunities to move forward, even from the technological side.

And this is also expected to increase public understanding of entrepreneurship which is not only limited to trading, but entrepreneurship has a very broad perspective of meaning. By conducting studies on technopreneurship and IT-preneurship and the development of vocational education in Indonesia. This paper is expected to be a description how importance technopreneurship and IT-preneurship through the world of vocational education.

\section{METHOD}

This study uses the literature study method by reviewing as many as 100 journals over the past 15 years related to technopreneurship and IT-preneur then linked to vocational education.

Based on literature data in previous studies, a systematic review was carried out which included two steps, namely as follows: first, the number of initial studies conducted in this review literature study was 100 journals that were found in the e-database. Second, after screening with journals related to technopreneurship and IT-preneur on the perspective of vocational education, the researchers obtained 45 journals.

\section{RESUlTS AND DISCUSSIONS}

\section{A. Entrepreneurship and IT (Information Technology}

The rapid development of Science and Technology, especially information, communication and technology (Information, Communication and Technology or ICT) which has developed and expanded in all fields, even penetrated into the world of entrepreneurship, known as technopreneurship and IT -preneurship.

Entrepreneurship and information technology are two things that cannot be separated. Basically entrepreneurship is a skill that can use labor, capital, technology and others or combine labor, capital, technology and others in order to get maximum profit (Saludung et al., 2019), whereas technology-based entrepreneurship or better known as technopreneurship has character and mindset. of entrepreneurs (Dsv et al., 2016).

Therefore technopreneurship or IT-preneurship is often referred to as a technology-based modern entrepreneur, in this knowledge-based economy era, they must be able to hone their creativity and innovation spirit and that must dominate entrepreneurship (Ebrahimi et al., n.d.). Creativity and innovation are the main focus of entrepreneurship education development $(\mathrm{H}$. Hartono \& Herman, 2019). Creativity in technology can create an effective and efficient ideas (Rubin, 2015), while innovation is the implementation of creativity. So that innovation in technology can be directly related to problem solving through thinking, applying and creating technology (Amboala \& Richardson, 2016).

Innovation and creativity are the foundation of technological knowledge (Amboala \& Richardson, 2016) and they cannot be separated at all. According to research conducted by Miller et al, where as many as $80 \%$ of respondents choose an innovation strategy that must be in line with technological aspects. The knowledge, entrepreneurial mindset and skills in managing IT possessed by vocational education 
graduates can lead them to have a modern entrepreneurial spirit based on technology or what is commonly known as technopreneurship and ITpreneurship (Miller, 2012).

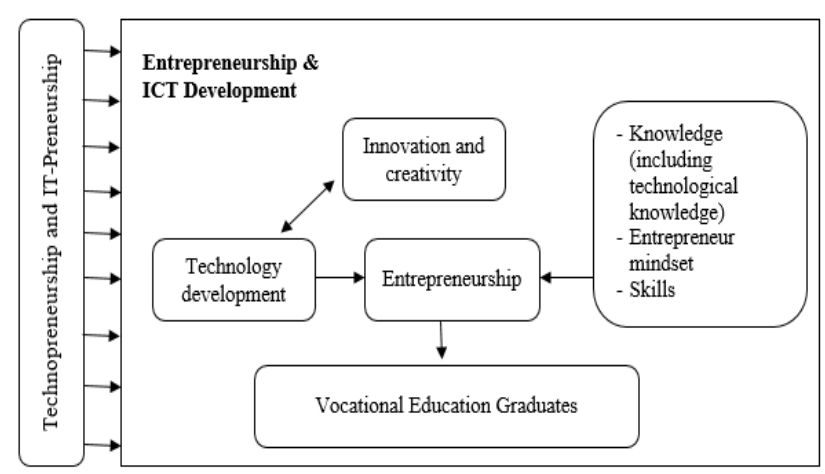

Figure 1. The Concept of Entrepreneurship and ICT development (adopted from (OECD, 1997); (Harsono, 2013); (Kosasih et al., 1991))

\section{B. Vocational Education Development in Indonesia}

Vocational education as mandated in Undangundang Number 12 of 2012 concerning Higher Education on August 10, 2012. The commitment of the government clearly states that vocational education as described in article 21 paragraph (1) is meant by "vocational education" is education that prepare students to be professionals with high employability skills/abilities.

Vocational education in Indonesia is organized by public and private universities, secondary schools, vocational training centers, course institutes, and community academies and PoliMedia (it is a public vocational university in the field of creative industry). Examples of vocational education fields include: hospitality, tourism, nursing, midwifery, performing arts, chemical analysis, computer graphic engineering, informatics management, animal nutrition, agricultural industrial technology, interior design, electrical engineering, electronic engineering, civil engineering, mechanical engineering, graphics engineering and publishing, accounting, administration and others.

All vocational education in Indonesia prioritizes in producing quality human resources (HR) to face the 4.0 industrial revolution era, because human resources are a determining factor for the success rate of Indonesia's national development in all fields (Nirwamati, 2012).

Based on Presidential Instruction No. 9 of 2016 concerning the revitalization of Vocational High School/Sekolah Menengah Kejuruan (SMK), this gives a big hope to vocational education to improve the quality of its graduates. The four points contained in this instruction cover the revitalization of the curriculum, educators and education personnel, cooperation and graduates (Dyah Widowati, 2015).

\section{Tecnepreneurship, IT-preneurship and Vocational Education}

In an emerging and increasingly complex world of competitive work, this makes vocational education graduates need cross-functional management and marketing skills, the benefits offered by applying technopreneurship and IT-preneurship in vocational education can be considered of three perspectives (Buhl, 2018): a) Industry, Students are looking for skills that will help them move into a different world of work; awareness that the position of the industry no longer offers job security due to increasing trends and outsourcing, but the industry is looking for workers who are able to think like entrepreneurs, and who can facilitate entrepreneurship in companies to cope with global competition and technological change (Goel \& Hasan, 2005).

b) Academic, technopreneurship and ITpreneurship can be studied and taught; Increase academic legitimacy about technopreneurship and ITpreneurship as important educational innovations and disciplines; Growing demand from industries that are interested in graduates who are spirited and have technopreneurship and IT-preneurship skills (Lisanti et al., 2017), and c) Public Policy, consistent findings in the Global Entrepreneurship Monitor (GEM), an international entrepreneurship research project currently entering its sixth year of study, illustrates that: Education and (vocational) training are among the most significant factors influencing the entrepreneurship sector (Oechslein, 2012); and There is a high correlation between educational attainment, especially vocational education in instilling confidence in graduates to be able to participate in the growth of high-potential entrepreneurship (Usman \& Raharjo, 2012).

Teaching of Technopreneurship and ITpreneurship in vocational education plays an important role in shaping attitudes, skills, behaviors, and culture to become technopreneurs after graduation (Cahyono, 2014). Technopreneurship and IT-preneurship education provides a blend of experiential learning, skills development and most importantly, a change in mindset. These concepts are parallel to build Technopreneurship and ITpreneurship for the Next Generation (Ejiogu \& Nwajiuba, 2012).

Technopreneurship and IT-preneurship education are needed to build the capital of future vocational education graduates. Entrepreneurship, technopreneurship and IT-preneurship are not just about creating a business plan and starting a new 
venture. It is also about creativity, innovation and growth, a way of thinking and acting that is relevant to all parts of the country, society and the entire ecosystem around it (Tan, 2005).

Vocational education should more encourage a culture of entrepreneurship education in developing the necessary skills, creativity, innovation, motivation, attitudes and behavior to prepare human resources to pursue technology-entrepreneurship opportunities. According to the World Economic Forum, entrepreneurship education programs, not only aim at entrepreneurship, but also improve behavior and mindset; building self-confidence, selfefficacy and leadership; creativity, innovation and the ability to solve problems; managing complexity and uncertainty; and identify opportunities and risks (Xiaodong et al., 2010)(Fernando et al., 2018).

\section{CONCLUSION}

Vocational education views technopreneurship and IT-preneurship as important to develop, because technopreneurship and IT-preneurship education provides a combination of learning experiences, skills development and most importantly, a change in mindset.

Skills development, like innovation and creativity, cannot be separated from technology development. This is because creativity in technology can create effective and efficient ideas, while innovation is the implementation of creativity. So that innovation in technology can be directly related to problem solving through thinking, applying and creating technology.

Therefore, the importance of instilling an entrepreneurial spirit, especially technopreneurship and IT-preneurship for vocational education graduates, can make them reliable competitors in the industrial world, especially in the digitalization era of the industrial revolution 4.0 which all uses this technology. And these concepts are parallel with building Technopreneurship and IT-preneurship for the Next Generation.

\section{REFERENCES}

Amboala, T., \& Richardson, J. (2016). Technological Entrepreneurship Framework for University Commercialization of Information Technology. Issues in Informing Science and Information Technology, 13, 279-290.

Buhl, A. (2018). Do it yourself - a lean startup toolbox for employee-driven green product innovation Anke Buhl. 526 Int. J. Entrepreneurship and Innovation Management, $22,526-544$.

Cahyono, J. I. (2014). Model Pembelajaran
Kewirausahaan Di Perguruan Tinggi ( Studi Kasus Di STIEBBANK Yogyakarta ) Entrepreneurship Learning Model in Higher Education ( Case Study In STIEBBANK Yogyakarta ). 55-60.

Dsv, I. I., Cunningham, M., \& Dsv, I. I. (2016). Factors Impacting On The Current Level Of Open Innovation And Ict Entrepreneurship In Africa. $\quad E J I S D C, \quad 73(1), \quad 1-23$. https://doi.org/10.1002/j.16814835.2016.tb00526.x

Dyah Widowati. (2015). Penyelarasan Kurikulum Pendidikan Vokasi (Study Kasus Smkn 10, Smk Adhikawacana Surabaya, Dan Politeknik Nsc Surabaya. Jurnal Bisnis \& Teknologi Politeknik NSC Surabaya, 2(1), 40-45.

Ebrahimi, P., Shafiee, B., Gholampour, A., \& Yousefi, L. (n.d.). Impact of Organizational Innovation , Learning Orientation and Entrepreneurship on SME Performance: The Moderating Role of Market Turbulence and ICT.

Ejiogu, A. O., \& Nwajiuba, C. A. (2012). The Need for Inclusion of Entrepreneurship Education in Nigerian School Curricula By. 4317244, 7-13. https://doi.org/10.1002/tie

Fernando, E., Wijaya, S., \& Enterpreneur, A. (2018). Impact of the Entrepreneur Course and Technology for University Students. September, 200-204.

Ganefri. (2013). The Development of ProductionBased Learning Approach to Entrepreneurial Spirit for Engineering Students. E-Journal: Asian Social Science, 9(12).

Goel, R. K., \& Hasan, I. (2005). An IT professional ' $s$ dilemma: be an entrepreneur or a consultant? https://doi.org/10.1007/s11066-005-9001-8

Güney-frahm, I. (2018). A new era for women? Some reflections on blind spots of ICT-based development projects for women, $\mathrm{s}$ entrepreneurship and empowerment. Gender, Technology and Development, O(0), 1-15. https://doi.org/10.1080/09718524.2018.150665 9

Harsono, A. (2013). Building Technopreneurship For Next Generation: How The Benefits Of Techno- Entrepreneurship Education Affect Career Intentions Of College Students. 3(1), 3140.

Hartono, H., \& Herman, R. T. (2019). A Study on Competitiveness of ICT Adoption and Entrepreneurship Orientation on SMEs in Indonesia. 2019 International Conference on Information Management and Technology (ICIMTech), 1(August), 53-57. 
Hartono, W. (2011). Pengembangan Technopreneurship : Upaya Peningkatan Daya Saing Bangsa Di Era Global. 2011 (Semantik).

Kosasih, W., S, L. L., \& Utama, D. W. (1991). Peranan Pendidikan Technopreneurship Untuk Pembangunan Berkelanjutan: Studi Konseptual. 79-88.

Lee, J., Kao, H., \& Yang, S. (2014). Service innovation and smart analytics for Industry 4.0 and big data environment. Procedia CIRP, 16, 3-8. https://doi.org/10.1016/j.procir.2014.02.001

Lisanti, Y., Luhukay, D., \& Mariani, V. (2017). IT Service and Risk Management Implementation for Online Startup SME Case Study: Online startup SME in Jakarta. November, 300-303.

Miller, E. a. (2012). innovation Leadership Study. Consulting:, Capgemini.

Nirwamati. (2012). Implementasi Praktik Kerja Industri Dalam Meningkatkan atkan Tenaga Kerja Siap Pakai Pada Smk Negeri 2 Kota Banda Aceh Nirmawati. Jurnal Pencerahan, 6(2), 84-88.

OECD. (1997). Technology Incubators: Nurturing Small Firms.

Oechslein, O. (2012). Examining Trust within the Team in IT Startup Companies - An Empirical Study in the People's Republic of China. https://doi.org/10.1109/HICSS.2012.261

Purnomo, S., Mesin, P. T., Tamansiswa, U. S., Mesin, P. T., \& Yogyakarta, U. N. (2018). Efektifitas Technopreneurship Dengan Model Pembelajaran Cooperative Learning By Effectiveness Technoreneurship With Cooperative Learning Method By Technopreneur For Students. 6(4).

Rojko, A. (2017). Industry 4.0 Concept: Background and Overview. International Journal of Interactive Mobile Technologies (IJIM), 11(5), 77. https://doi.org/10.3991/ijim.v11i5.7072
Rubin, E. al. . (2015). Knowledge flow in Technological Business Incubators: Evidence from Australia and Israel. Technovation.

Saludung, J., Hamid, S., \& Paramezwary, A. (2019). Technopreneurship and Ecopreneurship on Yellow Pumpkin ( Cucurbita maxima) to Produce An Industrial Based Product of Delicious Josua Pizza with A High Economic Value Technopreneurship and Ecopreneurship o n Yellow Pumpkin ( Cucurbita maxima ) to Produce. IOP Conf. Series: Journal of Physics: Conf. Series 1244, 2019. https://doi.org/10.1088/17426596/1244/1/012047

Statistik, B. P. (2019). No Title.

Tan, J. (2005). Firm growth in an emerging market economy: the experience of a Chinese IT entrepreneur. 5, 319-331.

Usman, H., \& Raharjo, N. E. (2012). Model Pendidikan Karakter Kewirausahaan di Sekolah Menengah Kejuruan. Jurnal Pendidikan Teknologi Dan Kejuruan, 21(2), 140-147.

Vojtovič, S., Navickas, V., \& Gruzauskas, V. (2016). Journal Of Security And Sustainability Issues ISSN 2029-7017 print / ISSN 2029-7025 online 2015 March Volume 4 Number 3. Journal of Security and Sustainability Issues, 5(2), 489499. https://doi.org/10.9770/jssi.2016.5.3(4)

Wahyudi, S. E., \& Tileng, K. G. (2017). Enhancing Technopreneurship Project Management System With Coaching And Mentoring Features.

Xiaodong, Z., Weiwei1, G., \& Greeven, M. (2010). An Empirical Study on the Relationship between Entrepreneur' s Social Network and Entrepreneurial Performance: the Case of the Chinese IT Industry. International Forum on Information Technology and Applications An. https://doi.org/10.1109/IFITA.2010.301 